\title{
PENANAMAN JIWA NASIONALISME DAN \\ PENDIDIKAN KARAKTER BANGSA PADA PEMBELAJARAN SEJARAH
}

\author{
Alfianoor Septiawan \\ Program Studi Pendidikan Sejarah \\ Fakultas Keguruan dan IImu Pendidikan \\ Universitas Lambung Mangkurat \\ Banjarmasin \\ alfianoorseptiawan@gmail.com
}

\begin{abstract}
ABSTRAK
Tulisan ini membahas mengenai penanaman jiwa nasionalisme dan pendidikan karakter bangsa pada pembelajaran sejarah. Pada masa sekarang jiwa nasionalisme dan karakter bangsa sudah mulai terkikis hal ini tidak lepas dari tidak maksimalnya pembelajaran sejarah diajarkan oleh pendidik. Hal tersebut menimbulkan memudarnya jiwa nasionalisme dan karakter bangsa karena masyarakat yang sudah mulai tidak mengenali lagi jati diri bangsanya karena telah kehilangan identitas bangsanya. Tentunya dalam pembelajaran sejarah memiliki berbagai manfaat yang tidak hanya sekedar mengajarkan mengenai peristiwa masa lampau, tetapi juga dapat membentuk jiwa nasionalisme dan karakter bangsa yang akan dapat membuat bangsa menjadi lebih baik lagi.
\end{abstract}

Kata Kunci: Nasionalisme, Pendidikan Karakter, dan Pembelajaran Sejarah.

\section{PENDAHULUAN}

Setiap pembelajaran tentunya memiliki tujuan yang harus dicapai, pada pembelajaran sejarah tentunya memiliki tujuan yang harus dapat dicapai peserta didik agar nilai-nilai dari pembelajaran sejarah dapat diterpenuhi. Setiap fenomena yang muncul dilingkungan masyarakat terkadang membuat masyarakat mudah untuk terpecah hal ini tentunya menjadi waspada bagi negara supaya nilai-nilai persatuan tidak luntur ataupun juga masyarakat kehilangan semangat nasionalismenya karena perpecahan yang muncul dimasyarakat. Dengan adanya jiwa nasionalisme pada masyarakat maka tentunya sedikit banyak akan memperkuat kekokohan bangsa dan negara. Pembelajaran sejarah sendiri dalam membentuk jiwa nasionalisme dapat dilihat dari materi yang diajarkan yakni perjuangan bangsa Indonesia dalam memperjuangkan kemerdekaannya dari para penjajah. Menurut Putro, H. P. N., dalam Abbas, E. W. (2017: 65) memaparkan bahwa dalam sebuah perjuangan suatu bangsa mengandung nilainilai yang merupakan identitas bangsa. Jadi setiap pembelajaran sejarah ketika 
membahas mengenai perjuangan bangsa tentunya terdapat nilai yang menjadi sebuah identitas terhadap jati diri masyarakat sebagai bagian dari bangsa, sehingga semangat jiwa nasionalisme dapat terbentuk yang nantinya akan menjadi karakter bangsa. Tentunya hal ini sangatlah penting karena disetiap zaman tentunya mempunyai tantangan tersendiri harus dihadapi tetapi sebuah bangsa harus dapat menghadapinya dengan terus menerus menanamkan jiwa semangat nasionalisme dan tetap menjaga karakter bangsa sehingga tidak luntur akibat perubahan kemajuan zaman.

\section{PEMBAHASAN}

\section{Jiwa Nasionalisme dan Pendidikan Karakter Pada Pembelajaran Sejarah}

Menurut Putro, H. P. N., dalam Abbas, E. W. (2017: 65) memaparkan bahwa pembelajaran sejarah hanya diarahkan untuk memberikan pemahaman mengenai masa lampau sampai masa sekarang, namun juga ditekankan terhadap berbagai aktivitas yang dapat memberikan pengalaman yang dapat menumbuhkan rasa kebangsaan dan kecintaan manusia secara luas. Dalam hal ini jelas sekali maksud dari pembelajaran sejarah sebagai sebuah pembelajaran tidak hanya mengenai sebatas teori tetapi juga terdapat sebuah nilai yang membentuk suatu individu yang menjadikan dirinya merasakan sebagai bagian dari bangsa dan negara tentunya dalam hal ini terbentuknya jiwa nasionalisme dan menjadi individu yang berkarakter yakni tidak menimbulkan perpecahan antar suku bangsa dan menghargai berbagai perbedaan yang ada.

Menurut Anis, M. Z. A. dalam Abbas, E. W. (2017: 250) menjelaskan bahwa proses nasionalisme sangat panjang akan tetapi bergerak perlahan dan pasti. Dalam penjelasan tersebut menjelaskan bahwa proses berjalannya sebuah nasionalisme berjalan tidak cepat namun membentuk secara perlahan sehingga walaupun pembelajaran sejarah diajarkan dengan baik dan sesuai tujuan yang diinginkan, tetapi dari apa yang diajarkan akan menjadi sebuah hasil dimasa yang akan datang karena ketika pendidik mengajarkan pembelajaran sejarah para peserta didik masih mengalami proses penanaman materi ajar sehingga implementasi dari apa yang diajarkan sesungguhnya adalah ketika mereka nantinya berada pada lingkungan masyarakat. Dalam pembelajaran sejarah tentunya adanya penanaman jati diri bangsa sehingga 
peserta didik dapat merasakan bahwa mereka bagian dari masyarakat berbangsa dan bernegara.

Menurut Anis, M. Z. A. dalam Abbas, E. W. (2017: 254) menjelaskan mengenai konsep jati diri bangsa yang dapat disetarakan dengan identitas bangsa. Dengan adanya identitas bangsa menjadi cerminan bangsa yang membedakan antara suatu bangsa dengan bangsa lainnya. Dengan lemahnya identitas bangsa tentunya akan melemahkan suatu bangsa dan negara. Pembelajaran sejarah sendiri membentuk masyarakat yang mengenai jati diri bangsa dengan berbagai materi ajar yang mengenalkan bangsa melalui pembelajaran yakni terhadap bentuk perjuangan para pahlawan bangsa baik nasional maupun lokal, dan juga mengenalkan bangunanbangunan yang mengandung nilai historis sebagai bagian dari pembentukan jati diri bangsa dan tentunya sebagai pengenalan identitas bangsa.

Pada pembelajaran sejarah tentunya membutuhkan adanya sebuah media sebagai sebagai alat bantu supaya nilai-nilai dari tujuan pembelajaran dapat tercapai dengan baik, salah satunya dengan mengenalkan obyek bersejarah sebagai media pembelajaran. Menurut Anis, M. Z. A. dalam Abbas, E. W. (2017: 257) menyatakan bahwa obyek bersejarah dapat membantu pemahaman terhadap jati diri bangsa. Tentunya dengan adanya obyek bersejarah dapat memberikan pemahaman terhadap peserta didik mengenai nilai-nilai ingin dicapai dalam pembelajaran sehingga peserta didik dapat mengenali identitas bangsa sendiri. Ketika peserta didik dapat mengenali identitas bangsa tentunya mereka mempunyai rasa memiliki sehingga akan menjaga dan ini nantinya akan dapat membentuk jiwa nasionalisme dan pendidikan karakter yang menjadi jati diri bangsa baik itu sikap saling membantu antar sesama, menghargai berbagai perbedaan yang terjadi dilingkungan sekitar, etika dan moral tentunya yang tertanam dalam jiwa raga suatu individu sehingga akan membentuk bangsa dan negara yang kuat dalam menghadapi serangan-serangan yang dapat mengancam persatuan dan kesatuan bangsa.

Menurut Anis, M. Z. A. (2016: 490) Sejarah sebagai ilmu hemat Kuntowijoyo mempunyai dua kegunaan, yaitu intrinsik dan ekstrinsik. Yakni pada intrinsik sendiri yaitu berkaitan dengan ilmu sejarah, sedangkan ekstrinsik berkaitan dengan fungsi 
pendidikan moral, penalaran, politik, kebijakan, perubahan, masa depan, ilmu bantu, rujukan, dan bukti. Sehingga dalam pembelajaran sejarah sangatlah penting untuk diajarkan pada peserta didik karena dalam pembelajaran sejarah tidak hanya mengajarkan mengenai peristiwa masa lampau yang bersifat teoritis tetapi juga mengajarkan dan menanamkan pendidikan moral yang dapat membentuk suatu individu menjadi individu yang lebih baik lagi yang dapat berguna bagi bangsa dan negara.

Menurut Anis, M. Z. A. (2015: 55) menjelaskan bahwa belajar sejarah adalah suatu dialog antara masa lampau dengan masa sekarang yang hasil dari analisisnya dapat dijadikan pertimbangan untuk menghadapi persoalan dimasa sekarang. Sehingga apabila kita maksudkan bahwa pembelajaran sejarah dapat menjadi sebuah acuan dalam menghadapi berbagai permasalahan yang terjadi pada masa lampau sebagai bentuk pelajaran dari peristiwa yang telah terjadi sehingga dapat diselesaiakan dengan baik, tentunya hal ini sangat baik bagi masyarakat berbangsa dan bernegara ketika terjadi permasalahan yang muncul dipermukaan, dengan pengalaman yang terjadi dimasa lampau dapat diselesaikan berdasarkan bentuk penyelesaian yang pernah dilakukan pada masa itu tentunya dengan telaah lebih lanjut karena setiap zaman memiliki permasalahan yang berbeda-beda.

Menurut Zaenal Arifin Anis, M. (2014: 484) menyatakan bahwa tujuan dari belajar sejarah yakni diantaranya adalah nation and character building. Yakni adalah bagaimana pembelajaran sejarah yang dikenal sebagai pembelajaran yang kerap mengajarkan materi mengenai peristiwa dimasa lampau dapat membentuk karakter diri sebagai bagian dari negara, sehingga tercipta rasa cinta dan jiwa nasionalisme dalam diri suatu individu. Dengan adanya pendidikan karakter tentunya akan dapat membentuk individu menjadi seseorang yang memiliki rasa cinta dan jiwa nasionalisme yang tinggi pada pembelajaran sejarah. Bahkan menurut Zaenal Arifin Anis, M. (2014: 484) berpendapat bahwa sejarah sebagai sebuah proses dapat dikatakan kalau karakter bangsa dibentuk dari sejarah bangsanya sendiri. Tentunya dalam hal ini pembelajaran sejarah memiliki peranan yang begitu penting dalam membentuk karakter bangsa sehingga menciptakan masyarakat bangsa yang berkarakter. Sehinga dalam 
pembelajaran sejarah sudah sepatutnya seluruh komponen dalam pendidikan untuk dapat meningkatkan kualitas mereka baik itu pendidik ataupun peserta didik dapat saling bersinergi dalam melaksanakan pembelajaran sejarah.

\section{SIMPULAN}

Pembelajaran sejarah merupakan pembelajaran yang tidak hanya mengajarkan mengenai peristiwa dari masa lampau, tetapi juga dapat membentuk jiwa nasionalisme dan karakter bangsa yang memungkan suatu bangsa dan negara menjadi negara yang kuat. Dalam membentuk jiwa nasionalisme dan karakter bangsa tidak lepas dari mengenal identitas bangsa karena dengan mengenalnya diri suatu individu terhadap identitas bangsanya maka rasa memiliki pun juga akan muncul dan akan merasa untuk menjaganya.

\section{SARAN}

Dalam tulisan ini penulis berharap tulisan ini tidak hanya sekedar sebagai bahan secara teoritis saja tetapi juga dapat diimplementasikan dalam pembelajaran sejarah, karena jika dapat diimplementasikan dalam bentuk pembelajaran sejarah maka setidaknya tujuan pembelajaran yang akan dicapai dalam materi ajar dapat tersampaikan dengan baik kepada peserta didik. 


\section{REFERENSI}

Abbas, E. W. (2017). Pendidikan Sejarah, Patriotisme \& Karakter Bangsa MalaysiaIndonesia.

Anis, M. Z. A. (2015). Sejarah Bukan Warisan Melainkan Pembelajaran.

Anis, M. Z. A. (2016). Sejarah, Kesadaran Sejarah dan Pupusnya Identitas Nasional.

Zaenal Arifin Anis, M. (2014). Sejarah, Pendidikan Sejarah, dan Pendidikan Karakter Dialog yang Tidak Pernah Dituntaskan. 